\title{
Analisis Beberapa Faktor Yang Berpengaruh Terhadap Kinerja UMKM Di Kota Surabaya
}

\author{
Moehammad Budi Widajanto \\ Sekolah Tinggi Ilmu Ekonomi Urip Sumoharjo, Surabaya
}

\begin{abstract}
This study discusses aspects of government policy, socio-cultural and economic aspects, aspects of the role of related institutions; Human resource aspects, financial aspects, production and operational technical aspects, and market and marketing aspects of the performance of Micro, Small and Medium Enterprises (MSMEs) in the city of Surabaya. The analysis was carried out using descriptive and inferential using multiple linear regression analysis of 100 samples of Small and Medium Enterprises that had permits in Surabaya City. Based on the results of the study it is also known that of the seven independent variables included in multiple linear regression models, six independent variables have a positive and significant influence on the performance of MSMEs, namely aspects of government policy; aspects of the role of related institutions; Human Resource Aspects; financial aspect; production and operational technical aspects; and market and marketing aspects. While one independent variable that does not have a significant influence on the performance of MSMEs is the socio-cultural and economic aspects (X2). The results of this study also show that the independent variable of human resources (X4) has a dominant influence on the variable according to MSME Performance Performance $(Y)$
\end{abstract}

Keywords: Economic Aspects, Human Resources, Small and Medium Enterprises

\section{Pendahuluan}

Salah satu sektor yang menopang perekonomian di Indonesia adalah sektor UMKM (usaha mikro, kecil dan menengah). Semenjak krisis ekonomi di Indonesia tahun 1998 hingga krisis keuangan global tahun 2008, UMKM terbukti mampu bertahan. Ekonom kerakyatan, pejuang reformasi, dan peneliti ekonomi dari Bank Dunia hampir semuanya sepakat bahwa usaha kecil dan menengah paling tahan terhadap guncangan krisis moneter. Mulyanto (2008) berpendapat bahwa roda ekonomi Indonesia bisa bergerak sedikit demi sedikit karena keberadaan UMKM. Oleh karena itu, menurut Radhi (2008) dalam sistem ekonomi kerakyatan, pengembangan industri pedesaan melalui usaha mikro, kecil dan menengah (UMKM) merupakan langkah strategic dalam pembangunan ekonomi bangsa.

Dilihat dari jumlah pelaku ekonomi, pelaku ekonomi terbesar di Indonesia sampai saat ini adalah kelompok ekonomi rakyat skala mikro, kecil dan menengah 
(UMKM) yaitu sebanyak 53.207.500 unit usaha atau 98,85\% dari seluruh unit usaha yang ada di Indonesia pada tahun 2010. (BPS dan Kementerian Koperasi dan UKM, 2012). Kelompok UMKM ini selama bertahun tahun telah mampu membuktikan keberadaannya sebagai pelaku ekonomi yang paling tangguh. Selama krisis, UMKM telah mampu menjadi katup pengaman bagi perkonomian nasional, khususnya di dalam mengatasi pengangguran terbuka yang semakin besar.

UMKM telah mampu menjadi motor pemulihan ekonomi dan mampu menyerap banyak tenaga kerja di Indonesia. Penyerapan tenaga kerja oleh UMKM mencapai 97,22\% dari total angkatan kerja di Indonesia pada tahun 2010. Selain itu, UMKM juga memberikan kontribusi yang lebih besar terhadap PDB Indonesia dibandngkan kelompok usaha besar. Kontribusi UMKM terhadap PDB Indonesia mencapai angka 57,83\% pada tahun 2010. (BPS dan Kementerian Koperasi dan UKM, 2012).

Sementara itu, jumlah UKM berdasarkan ijin di Kota Surabaya pada tahun 2012 sebanyak 9.429, yang terbagi antara UKM Perdagangan sebanyak 9.348 dan UKM Industri sebanyak 356. Jumlah UKM tersebut menurun jika dibandingkan pada tahun 2011 sebanyak 10.655, yang terbagi dalam UKM Perdagangan sebanyak 9.040 dan UKM Industri sebanyak 389. (Dinas Perdagangan dan Perindustrian Kota Surabaya, 2013).

Selain memiliki keunggulan karena daya fleksibilitasnya yang tinggi, UMKM juga menghadapi beberapa permasalahan yang harus ditanggulangi. Secara umum, permasalahan yang sering dihadapi UMKM adalah permodalan, pemasaran, kurangnya pengetahuan dan rendahnya kualitas Sumber Daya Manusia. Dalam konteks peningkatan kinerja usaha, penguasaan pengetahuan adalah faktor penting untuk mendongkrak kinerja. Rendahnya penguasaan pengetahuan pada UMKM dipengaruhi faktor internal dan faktor eksternal (Muttaqien, 2008). Faktor internal adalah (1) kurangnya kesadaran dan kemauan untuk menerapkan pengetahuan yang tepat guna, (2) keterbatasan modal untuk meningkatkan penguasaan teknologi, (3) kurangnya kemampuan untuk memanfaatkan dunia usaha dan (4) kurangnya akses terhadap sumber teknologi dan pengetahuan.

Faktor eksternal yang mempengaruhi adalah (1) hasil penelitian dan 
pengembangan yang belum tepat untuk pengembangan UMKM, (2) proses alih teknologi pada UMKM belum maksimal, (3) keterbatasan publikasi hasil penelitian dan pengembangan dan (4) skim pembiayaan yang masih terbatas dalam pengembangan ilmu pengetahuan dan teknologi.

Berbagai masalah yang dihadapi oleh UMKM tersebut menjadi penghambat bagi peningkatan kinerja usaha. Perlu ada upaya peningkatan kinerja UMKM agar mampu memberikan peran yang makin besar dalam perekonomian Indonesia. Oleh karena itu, diperlukan sebuah kajian untuk mengetahui faktor-faktor yang mempengaruhi kinerja UMKM.

Berdasarkan beberapa literatur yang ada dan penelitian sebelumya, faktor yang mempengaruhi kinerja UMKM bisa dikelmpokkan menjadi dua yaitu faktor eksternal dan faktor internal. Faktor eksternal terdiri dari tiga aspek yaitu: (1) aspek kebijakan pemerintah; (2) aspek sosial budaya, dan ekonomi; dan (3) aspek peranan lembaga terkait. Sedangkan faktor internal terdiri dari empat aspek yaitu: (1) aspek sumberdaya manusia; (2) aspek keuangan; (3) aspek teknis produksi dan operasional; dan (4) aspek pasar dan pemasaran.

\section{Landasan Teori}

\section{Definisi Usaha Mikro dan Kecil}

Badan Pusat Statistik mendefiniskan Usaha Mikro sebagai usaha yang memiliki tenaga kerja maksimal 4 orang . Sedangkan Usaha Kecil sebagaimana dimaksud Undang-undang No.9 Tahun 1995 adalah usaha produktif yang berskala kecil dan memenuhi kriteria kekayaan bersih paling banyak Rp.200.000.000,00 (dua ratus juta rupiah) tidak termasuk tanah dan bangunan tempat usaha atau memiliki hasil penjualan paling banyak Rp1.000.000.000,00 (satu milyar rupiah) per tahun serta dapat menerima kredit dari bank maksimal di atas Rp50.000.000,(lima puluh juta rupiah) sampai dengan Rp.500.000.000,- (lima ratus juta rupiah). World Bank mendefinisikan Usaha Kecil atau Small Enterprise, dengan kriteria: Jumlah karyawan kurang dari 30 orang; Pendapatan setahun tidak melebihi \$ 3 juta; Jumlah aset tidak melebihi \$ 3 juta.

Namun demikian pengertian terbaru mengenai Usaha Kecil menurut Undang-Undang Nomor 20 tahun 2008 adalah usaha ekonomi produktif yang 
berdiri sendiri, yang dilakukan oleh orang perorangan atau badan usaha yang bukan merupakan anak perusahaan atau bukan cabang perusahaan yang dimiliki, dikuasai, atau menjadi bagian baik langsung maupun tidak langsung dari usaha menengah atau usaha besar yang memiliki kekayaan bersih lebih dari Rp50.000.000,00 (lima puluh juta rupiah) sampai dengan paling banyak Rp500.000.000,00 (lima ratus juta rupiah) tidak termasuk tanah dan bangunan tempat usaha; atau mememiliki hasil penjualan tahunan lebih dari Rp.300.000.000,00(tiga ratus juta rupiah) sampai dengan paling banyak Rp2.500.000.000,00 (dua milyar lima ratus juta rupiah).

\section{Definisi Usaha Menengah}

Pengertian Usaha Menengah menurut Badan Pusat Statistik adalah usaha yang memiliki tenaga kerja antara 20 orang hingga 99 orang. Sedangkan Usaha Menengah sebagaimana dimaksud Inpres No.10 tahun 1998 adalah usaha bersifat produktif yang memenuhi kriteria kekayaan usaha bersih lebih besar Rp.200.000.000,00 (dua ratus juta rupiah) sampai dengan paling banyak sebesar Rp.10.000.000.000,00, (sepuluh milyar rupiah) tidak termasuk tanah dan bangunan tempat usaha serta dapat menerima kredit dari bank sebesar Rp.500.000.000,00 (lima ratus juta rupiah) s/d Rp.5.000.000.000,00 (lima milyar rupiah). World Bank mendefinisikan Usaha Menengah atau Medium Enterprise adalah usaha dengan kriteria: Jumlah karyawan maksimal 300 orang; Pendapatan setahun hingga sejumlah \$ 15 juta; Jumlah aset hingga sejumlah $\$ 15$ juta.

Sedangkan pengertian Usaha Menengah menurut Undang-Undang Nomor 20 tahun 2008 adalah usaha ekonomi produktif yang berdiri sendiri, yang dilakukan oleh orang perseorangan atau badan usaha yang bukan merupakan anak perusahaan atau cabang perusahaan yang dimiliki, dikuasai, atau menjadi bagian baik langsung maupun tidak langsung dengan Usaha Kecil atau usaha besar yang memiliki kekayaan bersih lebih dari Rp.500.000.000,00 (lima ratus juta upiah) sampai dengan paling banyak Rp.10.000.000.000,00 (sepuluh milyar rupiah) tidak termasuk tanah dan bangunan tempat usaha; atau memiliki hasil penjualan tahunan lebih dari Rp2.500.000.000,00 (dua milyar lima ratus juta rupiah) sampai dengan paling banyak Rp.50.000.000.000,00 (lima puluh milyar rupiah). Secara detil berbagai definisi usaha kecil dan menengah dipaparkan pada Tabel 1. 
Tabel 1. Definisi dan Kriteria UMKM Menurut Berbagai Sumber

\begin{tabular}{|c|c|c|}
\hline Organisasi & Jenis Usaha & Kriteria \\
\hline \multirow{3}{*}{$\begin{array}{l}\text { Biro Pusat } \\
\text { Statistik (BPS) }\end{array}$} & Usaha Mikro & Pekerja maksimal 4 orang \\
\hline & Usaha Kecil & Pekerja $5-19$ orang \\
\hline & $\begin{array}{l}\text { Usaha } \\
\text { Menengah }\end{array}$ & Pekerja $20-99$ orang \\
\hline \multirow[t]{2}{*}{$\begin{array}{l}\text { Bank Indonesia } \\
\text { (BI) }\end{array}$} & $\begin{array}{l}\text { Usaha Mikro } \\
\text { (SK Dir BI No } \\
\text { 31/24/KEP/ DIR } \\
\text { Tgl } 5 \text { Mei 1998) }\end{array}$ & $\begin{array}{l}\text { - Usaha yang dijalankan oleh rakyat } \\
\text { miskin atau mendekati miskin } \\
\text { - Dimiliki oleh keluarga sumber daya } \\
\text { lokal dan teknologi sederhana } \\
\text { - Lapangan usaha mudah untuk exit } \\
\text { dan entry }\end{array}$ \\
\hline & $\begin{array}{l}\text { Usaha } \\
\text { Menengah } \\
\text { (SK Dir BI No } \\
\text { 30/45/Dir/ UK } \\
\text { tgl 5 Januari } \\
\text { 1997) }\end{array}$ & $\begin{array}{l}\text { - } \text { Aset }<\text { Rp } 5 \mathrm{M} \text { untuk industri } \\
\text { - } \text { Aset }<\text { Rp } 600 \text { juta diluar tanah \& } \\
\text { bangunan } \\
\text { - } \text { Omzet tahunan }<\text { Rp } 3 \mathrm{M}\end{array}$ \\
\hline \multirow[t]{2}{*}{ Bank Dunia } & Usaha Kecil & $\begin{array}{l}\text { - Jumlah karyawan }<30 \text { orang } \\
\text { - Pendapatan setahun }<\$ 3 \text { juta } \\
\text { - Jumlah aset }<\$ 3 \text { juta }\end{array}$ \\
\hline & $\begin{array}{l}\text { Usaha } \\
\text { Menengah }\end{array}$ & $\begin{array}{l}\text { - Jumlah karyawan } 30-300 \text { orang } \\
\text { - Pendapatan setahun hingga sejumlah } \\
\text { \$ } 15 \text { juta } \\
\text { - Jumlah aset hingga sejumlah } \$ 15 \\
\text { juta }\end{array}$ \\
\hline \multirow[t]{2}{*}{$\begin{array}{l}\text { Kementerian } \\
\text { Koperasi dan } \\
\text { UKM } \\
\text { (Undang-undang } \\
\text { No. } 20 \text { tahun } \\
\text { 2008) }\end{array}$} & Usaha Kecil & $\begin{array}{l}\text { Kekayaan Bersih (tidak termasuk } \\
\text { tanah \& bangunan) Lebih dari Rp. } \\
50 \text { juta sampai dengan paling banyak } \\
\text { Rp. } 500 \text { juta } \\
\text { - Hasil Penjualan Tahunan } \\
\text { (Omset/tahun) Lebih dari Rp.300 } \\
\text { juta sampai dengan paling banyak } \\
\text { Rp. 2,5 Milyar }\end{array}$ \\
\hline & $\begin{array}{l}\text { Usaha } \\
\text { Menengah }\end{array}$ & $\begin{array}{l}\text { Kekayaan Bersih (tidak termasuk } \\
\text { tanah \& bangunan) Lebih dari Rp. } \\
500 \text { juta sampai dengan paling } \\
\text { banyak Rp. } 10 \text { Milyar } \\
\text { - Hasil Penjualan Tahunan } \\
\text { (Omset/tahun) Lebih dari Rp. } 2,5 \\
\text { Milyar sampai dengan paling banyak } \\
\text { Rp. 50 Milyar }\end{array}$ \\
\hline
\end{tabular}

Sumber : Bank Indonesia; http://infoukm.wordpress.com (diolah) 


\section{Metodologi Penelitian}

\section{Propulasi dan Sampel}

Populasi dalam penelitian ini adalah seluruh UKM yang ada di Kota yang telah memiliki Ijin dari Pemerintah Kota Surabaya pada tahun 2012, khususnya UKM bidang industri sebanyak 389. Jumlah sampel dalam penelitian ini sebanyak 100 atau $25,7 \%$ dari seluruh populasi yang berjumlah 389. Pengambilan sampel dilakukan dengan metode simple random sampling dari lima wilayah di Kota Surabaya, dimana masing-masing wilayah diambil sampel dalam jumlah yang sama, yaitu Surabaya Timur sebanyak 20, Surabaya Barat sebanyak 20, Surabaya Selatan sebanyak 20, Surabaya Utara sebanyak 20, dan Surabaya Pusat sebanyak 20.

\section{Identifikasi dan Definisi Operasional Variabel}

Variabel-variabel yang dibahas dalam penelitian ini meliputi:

1. Variabel Bebas $X_{1}$ (Aspek kebijakan pemerintah)

Dalam penelitian ini variabel aspek kebijakan pemerintah adalah adanya kebijakan pemerintah yang memiliki dampak terhadap kinerja UMKM. Variabel aspek kebijakan pemerintah diukur berdasarkan tanggapan responden (pelaku UMKM) terhadap pernyataan dalam kuisioner, yaitu :

a. Pemerintah telah membuat kebijakan agar UMKM memiliki Akses terhadap permodalan dan pembiayaan

b. Pemerintah telah melakukan pembinaan terhadap UMKM melalui Dinas/SKPD terkait.

c. Pemerintah telah mengeluarkan peraturan dan regulasi yang pro bisnis tehadap UMKM.

d. Pemerintah telah melakukan Penyiapan lokasi usaha dan penyediaan informasi bagi UMKM

Jawaban responden terhadap masing-masing pernyataan yang terkait dengan variabel tersebut memiliki rentang 5 skala sbb: Sangat Setuju, memiliki skor 5; Setuju, memiliki skor 4; Cukup Setuju, memiliki skor 3; Tidak Setuju, memiliki skor 2; dan Sangat Tidak Setuju, memiliki skor 1. 
2. Variabel Bebas $X_{2}$ (Aspek sosial budaya, dan ekonomi)

Dalam penelitian ini variabel aspek sosial budaya, dan ekonomi adalah adanya aspek sosial, budaya dan ekonomi yang memiliki dampak terhadap kinerja UMKM. Variabel ini diukur dari persepsi responden (pelaku UMKM) yang tercermin dari hasil jawaban dalam kuisioner terhadap pernyataan dalam kuisioner, yaitu :

a. Daya beli masyarakat cukup tinggi.

b. Masyarakat gemar membeli produk UMKM

c. Lingkungan bisnis saat ini menunjukkan adanya Iklim usaha dan investasi yang kondusif.

Jawaban responden terhadap masing-masing pernyataan yang terkait dengan variabel tersebut memiliki rentang 5 skala sbb: Sangat Setuju, memiliki skor 5; Setuju, memiliki skor 4; Cukup Setuju, memiliki skor 3; Tidak Setuju, memiliki skor 2; dan Sangat Tidak Setuju, memiliki skor 1.

3. Variabel Bebas $\mathrm{X}_{3}$ (Aspek peranan lembaga terkait)

Dalam penelitian ini variabel aspek peranan lembaga terkait adalah adanya bantuan permodalan, bimbingan teknis, pelatihan, pendampingan, monitoring dan evaluasi yang dilakukan oleh lembaga terkait terhadap UMKM. Variabel ini diukur dari hasil tanggapan responden terhadap pernyataan dalam kuisioner, yaitu :

a. Lembaga terkait telah memberikan Bantuan Permodalan bagi UMKM.

b. Lembaga terkait telah memberikan bimbingan teknis/pelatihan kepada UMKM

c. Lembaga terkait telah memberikan pendampingan kepada UMKM

d. Lembaga terkait telah melakukan monitoring dan evaluasi kepada UMKM Jawaban responden terhadap masing-masing pernyataan yang terkait dengan variabel tersebut memiliki rentang 5 skala sbb: Sangat Setuju, memiliki skor 5; Setuju, memiliki skor 4; Cukup Setuju, memiliki skor 3; Tidak Setuju, memiliki skor 2; dan Sangat Tidak Setuju, memiliki skor 1.

4. Variabel Bebas $\mathrm{X}_{4}$ (Aspek sumberdaya manusia)

Dalam penelitian ini variabel aspek sumberdaya manusia adalah aspek kualitas 
sumberdaya manusia yang dimiliki oleh pelaku UMKM. Variabel ini diukur dari persepsi responden yang tercermin dari hasil jawaban dalam kuisioner terhadap pernyataan dalam kuisioner, yaitu :

a. Tingkat pendidikan formal yang dcapai oleh pelaku UMKM.

Jawaban responden terhadap pernyataan tersebut memiliki rentang skala sbb:

- Lulus sarjana (S1/S2/S3), memiliki skor 5

- Lulus Diploma (D1/D2/D3), memiliki skor 4

- Lulus SLTA, memiliki skor 3

- Lulus SLTP, memiliki skor 2

- Maksimum lulus SD, memiliki skor 1

b. Jiwa kepemimpinan yang dimiliki oleh Pelaku UMKM.

Jawaban responden terhadap pernyataan tersebut memiliki rentang skala sbb:

- Sangat baik, memiliki skor 5

- Baik, memiliki skor 4

- Cukup baik, memiliki skor 3

- Tidak baik, memiliki skor 2

- Sangat tidak baik, memiliki skor 1

c. Pengalaman/lama berusaha yang dicapai oleh pelaku UMKM Jawaban responden terhadap pernyataan tersebut memiliki rentang skala sbb:

- 15 tahun atau lebih, memiliki skor 5

- 10 sampai 14, memiliki skor 4

- 6 sampai 9 tahun, memiliki skor 3

- Lebih dari 1 tahun sampai 5 tahun, memiliki skor 2

- Maksimal 1 tahun, memiliki skor 1

d. Motivasi dan keterampilan yang dimiliki oleh pelaku UMKM Jawaban responden terhadap pernyataan tersebut memiliki rentang skala sbb:

- Sangat baik, memiliki skor 5 
- Baik, memiliki skor 4

- Cukup baik, memiliki skor 3

- Tidak baik, memiliki skor 2

- Sangat tidak baik, memiliki skor 1

5. Variabel Bebas $\mathrm{X}_{5}$ (Aspek keuangan)

Dalam penelitian ini aspek keuangan adalah kondisi keuangan UMKM yang mempengaruhi kinerja UMKM. Variabel ini diukur dari jawaban responden (pelaku UMKM) terhadap pernyataan dalam kuisioner, yaitu :

a. Rasio modal sendiri terhadap total dana yang digunakan sebagai modal usaha (dalam persen).

Jawaban responden terhadap pernyataan tersebut memiliki rentang skala sbb: (a) 80\%-100\%, memiliki predikat Sangat Baik; (b) 60\%79\%, memiliki predikat Baik; (c) 40\%-59\%, memiliki predikat Cukup Baik; (d) 20\%-39\%, memiliki predikat Jelek; (e) 0\%-19\%, memiliki predikat Sangat Jelek.

b. Tingkat keuntungan UMKM (sebagai prosentase dari modal yang dipakai).

Jawaban responden terhadap pernyataan tersebut memiliki rentang skala sbb: (a) lebih dari atau sama dengan 65\% ( $\geq 65 \%$ ), memiliki predikat Sangat Baik; (b) 45\%-64\%, memiliki predikat Baik; (c) 25\%44\%, memiliki predikat Cukup Baik; (d) 5\%-24\%, memiliki predikat Jelek, (e) kurang dari 5\%, memiliki predikat Sangat Jelek.

6. Variabel Bebas $\mathrm{X}_{6}$ (aspek teknis produksi dan operasional)

Dalam penelitian ini aspek teknis produksi dan operasional adalah segala aspek yang terkait dengan proses produksi yang mempengaruhi kinerja UMKM. Variabel ini diukur dari hasil jawaban responden (pelaku UMKM) terhadap pernyataan dalam kuisioner, yaitu :

a. Tersedia bahan baku yang memadai bagi kebutuhan UMKM.

b. Tersedia mesin dan peralatan yang memadai bagi UMKM.

c. UMKM telah menggunakan teknologi modern 
Jawaban responden terhadap pernyataan tersebut memiliki rentang skala sbb:

- Sangat baik, memiliki skor 5

- Baik, memiliki skor 4

- Cukup baik, memiliki skor 3

- Tidak baik, memiliki skor 2

- Sangat tidak baik, memiliki skor 1

7. Variabel Bebas $\mathrm{X}_{7}$ (Aspek pasar dan pemasaran)

Dalam penelitian ini aspek pasar dan pemasaran adalah hal-hal yang terkait aspek pasar dan pemasaran yang mempengaruhi kinerja UMKM. Variabel ini diukur dari persepsi responden (pelaku UMKM) dari hasil jawaban terhadap pernyataan dalam kuisioner, yaitu :

a. Permintaan pasar terhadap produk UMKM relatif besar.

b. Kegiatan promosi sudah dilakukan oleh UMKM.

c. Tersedia saluran distribusi bagi UMKM.

Jawaban responden terhadap pernyataan tersebut memiliki rentang skala sbb:

- Sangat baik, memiliki skor 5

- Baik, memiliki skor 4

- Cukup baik, memiliki skor 3

- Tidak baik, memiliki skor 2

- Sangat tidak baik, memiliki skor 1

8. Variabel Terikat Y (kinerja UMKM)

Dalam penelitian ini variabel kinerja UMKM adalah tingkat keberhasilan UMKM dalam menjalankan usahanya. Variabel ini diukur dari jawaban responden (pelaku UMKM) terhadap pernyataan dalam kuisioner, yaitu :

a. Penjualan produk UMKM mengalami peningkatan.

b. Modal yang dimiliki oleh UMKM mengalami peningkatan.

c. Tenaga kerja yang dimiliki oleh UMKM mengalami peningkatan.

d.Laba UMKM mengalami peningkatan.

Jawaban responden terhadap masing-masing pernyataan yang terkait dengan variabel tersebut memiliki rentang 5 skala sbb: Sangat Setuju, memiliki skor 5; 
Setuju, memiliki skor 4; Cukup Setuju, memiliki skor 3; Tidak Setuju, memiliki skor 2; dan Sangat Tidak Setuju, memiliki skor 1.

\section{Teknik Analisis}

Penelitian ini menggunakan model analisis regresi linier berganda dengan persamaan regresi linier berganda tersebut sebagai berikut:

$$
Y=\beta_{0}+\beta_{1} X_{1}+\beta_{2} X_{2}+\beta_{3} X_{3}+\beta_{4} X_{4}+\beta_{5} X_{5}+\beta_{6} X_{6}+\beta_{7} X_{7}+e
$$

Keterangan :

$\mathrm{Y} \quad=$ kinerja UMKM

$\mathrm{X}_{1} \quad=$ aspek kebijakan pemerintah

$\mathrm{X}_{2} \quad=$ aspek sosial budaya, dan ekonomi

$\mathrm{X}_{3} \quad=$ aspek peranan lembaga terkait

$\mathrm{X}_{4} \quad=$ aspek sumberdaya manusia

$\mathrm{X}_{5} \quad=$ aspek keuangan

$\mathrm{X}_{6} \quad=$ aspek teknis produksi dan operasional

$\mathrm{X}_{7} \quad=$ aspek pasar dan pemasaran

$\beta_{0} \quad=$ Konstanta

$\beta_{1}, \beta_{2}, \beta_{3}, \beta_{4}, \beta_{5}, \beta_{6}, \beta_{7}=$ Koefisien regresi untuk masing-masing variabel bebas

e $\quad=$ Kesalahan pengganggu (error term)

Untuk menguji signifikansi pengaruh varibel aspek kebijakan pemerintah $\left(\mathrm{X}_{1}\right)$, aspek sosial budaya, dan ekonomi $\left(\mathrm{X}_{2}\right)$, aspek peranan lembaga terkait $\left(\mathrm{X}_{3}\right)$, aspek sumberdaya manusia $\left(\mathrm{X}_{4}\right)$, aspek keuangan $\left(\mathrm{X}_{5}\right)$, aspek teknis produksi dan operasional $\left(\mathrm{X}_{6}\right)$, aspek pasar dan pemasaran $\left(\mathrm{X}_{7}\right)$ terhadap variabel kinerja UMKM (Y), maka dapat diuji secara simultan (uji F) dan secara parsial (uji t)

Uji $\mathrm{F}$ adalah uji yang digunakan untuk mengetahui signifikansi pengaruh secara simultan dari varibel bebas aspek kebijakan pemerintah $\left(\mathrm{X}_{1}\right)$, aspek sosial budaya, dan ekonomi $\left(\mathrm{X}_{2}\right)$, aspek peranan lembaga terkait $\left(\mathrm{X}_{3}\right)$, aspek sumberdaya manusia $\left(\mathrm{X}_{4}\right)$, aspek keuangan $\left(\mathrm{X}_{5}\right)$, aspek teknis produksi dan operasional $\left(\mathrm{X}_{6}\right)$, aspek pasar dan pemasaran $\left(\mathrm{X}_{7}\right)$ terhadap variabel kinerja UMKM (Y). Hal ini dilakukan dengan membandingkan nilai $\mathrm{F}$ hitung dengan $\mathrm{F}$ tabel.

\section{Hasil Dan Pembahasan}

\section{Uji F}

Dari hasil perhitungan seperti terlihat di Lampiran 1, nilai $\mathrm{F}$ hitung sebesar 4,314 dengan nilai probabilitas atau signifikansi sebesar 0,000 (kurang dari $\alpha=0,05)$. Hal ini berarti $\mathrm{H}_{0}$ ditolak atau $\mathrm{H}_{1}$ diterima yang berarti bahwa keseluruhan variabel bebas aspek kebijakan pemerintah $\left(\mathrm{X}_{1}\right)$; aspek sosial budaya, 
dan ekonomi $\left(\mathrm{X}_{2}\right)$; aspek peranan lembaga terkait $\left(\mathrm{X}_{3}\right)$, aspek sumberdaya manusia $\left(\mathrm{X}_{4}\right)$; aspek keuangan $\left(\mathrm{X}_{5}\right)$, aspek teknis produksi dan operasional $\left(\mathrm{X}_{6}\right)$; dan aspek pasar dan pemasaran $\left(\mathrm{X}_{7}\right)$ secara simultan memiliki pengaruh signifikan terhadap kinerja UMKM (Y).

\section{Uji t}

Dari hasil perhitungan seperti terlihat di Lampiran 1, nilai t hitung untuk X1 (aspek kebijakan pemerintah) sebesar 2,192 dengan nilai probabilitas atau signifikansi sebesar 0,031 (kurang dari $\alpha=0,05$ ). Hal ini berarti $\mathrm{H}_{0}$ ditolak atau $\mathrm{H}_{1}$ diterima yang berarti bahwa variabel bebas X1 (aspek kebijakan pemerintah) memiliki pengaruh yang signifikan terhadap variabel terikat Y (kinerja UMKM).

Nilai t hitung untuk X2 (aspek sosial budaya, dan ekonomi) sebesar 0,081 dengan nilai probabilitas atau signifikansi sebesar 0,937 (lebih besar dari $\alpha=0,05)$. Hal ini berarti $\mathrm{H}_{0}$ diterima atau $\mathrm{H}_{1}$ ditolak yang berarti bahwa variabel bebas X2 (aspek sosial budaya, dan ekonomi) tidak memiliki pengaruh yang signifikan terhadap variabel terikat Y (kinerja UMKM).

Nilai t hitung untuk X3 (aspek peranan lembaga terkait) sebesar 2,313 dengan nilai probabilitas atau signifikansi sebesar 0,029 (kurang dari $\alpha=0,05$ ). Hal ini berarti $\mathrm{H}_{0}$ ditolak atau $\mathrm{H}_{1}$ diterima yang berarti bahwa variabel bebas $\mathrm{X} 3$ (aspek peranan lembaga terkait) memiliki pengaruh yang signifikan terhadap variabel terikat Y (kinerja UMKM).

Nilai t hitung untuk X4 (aspek sumberdaya manusia) sebesar 3,405 dengan nilai probabilitas atau signifikansi sebesar 0,004 (kurang dari $\alpha=0,05$ ). Hal ini berarti $\mathrm{H}_{0}$ ditolak atau $\mathrm{H}_{1}$ diterima yang berarti bahwa variabel bebas $\mathrm{X} 4$ (aspek sumberdaya manusia) memiliki pengaruh yang signifikan terhadap variabel terikat Y (kinerja UMKM).

Nilai t hitung untuk X5 (aspek keuangan) sebesar 3,132 dengan nilai probabilitas atau signifikansi sebesar 0,015 (kurang dari $\alpha=0,05$ ). Hal ini berarti $\mathrm{H}_{0}$ ditolak atau $\mathrm{H}_{1}$ diterima yang berarti bahwa variabel bebas X5 (aspek keuangan) memiliki pengaruh yang signifikan terhadap variabel terikat $\mathrm{Y}$ (kinerja UMKM).

Nilai t hitung untuk X6 (aspek teknis produksi dan operasional) sebesar 
2,507 dengan nilai probabilitas atau signifikansi sebesar 0,023 (kurang dari $\alpha=0,05)$. Hal ini berarti $\mathrm{H}_{0}$ ditolak atau $\mathrm{H}_{1}$ diterima yang berarti bahwa variabel bebas X6 (aspek teknis produksi dan operasional) memiliki pengaruh yang signifikan terhadap variabel terikat Y (kinerja UMKM).

Nilai t hitung untuk X7 (aspek pasar dan pemasaran) sebesar 3,214 dengan nilai probabilitas atau signifikansi sebesar 0,012 (lebih dari $\alpha=0,05$ ). Hal ini berarti $\mathrm{H}_{0}$ ditolak atau $\mathrm{H}_{1}$ diterima yang berarti bahwa variabel bebas $\mathrm{X} 7$ (aspek pasar dan pemasaran) memiliki pengaruh yang signifikan terhadap variabel terikat Y (kinerja UMKM).

\section{Uji Koefisien Determinasi Parsial}

Untuk menguji hipotesis ketiga yang menyatakan bahwa dari kelima faktor tersebut, aspek sumberdaya manusia memiliki pengaruh dominan terhadap kinerja Usaha Mikro, Kecil dan Menengah (UMKM) di Kota Surabaya, digunakan uji koefisien determinasi parsial $\left(\mathrm{r}^{2}\right)$. Dari hasil perhitungan diperoleh koefisien determinasi parsial untuk masing-masing variabel bebas seperti tampak pada Tabel 5. Dari tabel tersebut terlihat bahwa $\mathrm{X}_{4}$ (aspek sumberdaya manusia) mempunyai nilai koefisien determinasi parsial $\left(\mathrm{r}^{2}\right)$ yang terbesar dibandingkan variabel lainnya yaitu 0,1568 atau $15,68 \%$. Hal ini menunjukkan bahwa variabel $\mathrm{X}_{4}$ (aspek sumberdaya manusia) memiliki pengaruh dominan terhadap variabel terikat $\mathrm{Y}$ (kinerja UMKM)

Tabel 5. Nilai Koefisien Determinasi Parsial

\begin{tabular}{|l|c|c|}
\hline \multicolumn{1}{|c|}{ Variabel Bebas } & $\begin{array}{c}\text { Koefisien } \\
\text { korelasi parsial } \\
(\mathbf{r})\end{array}$ & $\begin{array}{c}\text { Koefisien } \\
\text { determinasi } \\
\left.\text { parsial ( } \mathbf{r}^{\mathbf{2}}\right)\end{array}$ \\
\hline $\mathrm{X}_{1}$ (aspek kebijakan pemerintah) & 0,244 & 0,0595 \\
\hline $\mathrm{X}_{2}$ (aspek sosial budaya, dan ekonomi) & 0,098 & 0,0096 \\
\hline $\mathrm{X}_{3}$ (aspek peranan lembaga terkait) & 0,266 & 0,0708 \\
\hline $\mathrm{X}_{4}$ (aspek sumberdaya manusia) & 0,396 & 0,1568 \\
\hline $\mathrm{X}_{5}$ (aspek keuangan) & 0,347 & 0,1204 \\
\hline $\mathrm{X}_{6}$ (aspek teknis produksi dan operasional) & 0,293 & 0,0858 \\
\hline $\mathrm{X}_{7}$ (aspek pasar dan pemasaran) & 0,372 & 0,1384 \\
\hline
\end{tabular}

Sumber : Lampiran 1

Dari hasil perhitungan regresi linier berganda terlihat bahwa variabel $\mathrm{X}_{1}$ 
(aspek kebijakan pemerintah) memiliki koefisien regresi bernilai positif sebesar 0,171 yang berarti aspek kebijakan pemerintah memiliki pengaruh positif terhadap kinerja UMKM (Y). Hal ini berarti semakin baik aspek kebijakan pemerintah semakin meningkat kinerja UMKM.

Variabel $\mathrm{X}_{2}$ (aspek sosial budaya, dan ekonomi) memiliki koefisien regresi bernilai positif sebesar 0,006 yang berarti aspek sosial budaya, dan ekonomi memiliki pengaruh positif terhadap kinerja UMKM (Y). Hal ini berarti semakin baik aspek sosial budaya, dan ekonomi semakin meningkat kinerja UMKM.

Variabel $\mathrm{X}_{3}$ (aspek peranan lembaga terkait) memiliki koefisien regresi bernilai positif sebesar 0,155 yang berarti aspek peranan lembaga terkait memiliki pengaruh positif terhadap kinerja UMKM (Y). Hal ini berarti semakin baik aspek peranan lembaga terkait semakin meningkat kinerja UMKM.

Variabel $\mathrm{X}_{4}$ (aspek sumberdaya manusia) memiliki koefisien regresi bernilai positif sebesar 0,269 yang berarti aspek sumberdaya manusia memiliki pengaruh positif terhadap kinerja UMKM (Y). Hal ini berarti semakin baik aspek sumberdaya manusia semakin meningkat kinerja UMKM.

Variabel $\mathrm{X}_{5}$ (aspek keuangan) memiliki koefisien regresi bernilai positif sebesar 0,166 yang berarti aspek keuangan memiliki pengaruh positif terhadap kinerja UMKM (Y). Hal ini berarti semakin baik aspek keuangan semakin meningkat kinerja UMKM.

Variabel $\mathrm{X}_{6}$ (aspek teknis produksi dan operasional) memiliki koefisien regresi bernilai positif sebesar 0,173 yang berarti aspek teknis produksi dan operasional memiliki pengaruh positif terhadap kinerja UMKM (Y). Hal ini berarti semakin baik aspek teknis produksi dan operasional semakin meningkat kinerja UMKM.

Variabel $\mathrm{X}_{7}$ (aspek pasar dan pemasaran) memiliki koefisien regresi bernilai positif sebesar 0,225 yang berarti aspek pasar dan pemasaran memiliki pengaruh positif terhadap kinerja UMKM (Y). Hal ini berarti semakin baik aspek pasar dan pemasaran semakin meningkat kinerja UMKM.

Koefisien Determinasi Berganda $\left(\mathrm{R}^{2}\right)$ sebesar 0,654, yang berarti bahwa keseluruhan variabel bebas aspek kebijakan pemerintah $\left(\mathrm{X}_{1}\right)$; aspek sosial budaya, 
dan ekonomi $\left(\mathrm{X}_{2}\right)$; aspek peranan lembaga terkait $\left(\mathrm{X}_{3}\right)$, aspek sumberdaya manusia $\left(\mathrm{X}_{4}\right)$; aspek keuangan $\left(\mathrm{X}_{5}\right)$, aspek teknis produksi dan operasional $\left(\mathrm{X}_{6}\right)$; dan aspek pasar dan pemasaran $\left(\mathrm{X}_{7}\right)$ memiliki kontribusi sebesar $65,4 \%$ terhadap naik turunnya Y (kinerja UMKM). Sedangkan sisanya 34,6 \% disebabkan oleh faktor lain di luar model.

Hasil Uji F seperti terlihat di Lampiran 1, memperlihatkan nilai F hitung sebesar 4,314 dengan nilai probabilitas atau signifikansi sebesar 0,000 (kurang dari $\alpha=0,05)$. Hal ini berarti $\mathrm{H}_{0}$ ditolak atau $\mathrm{H}_{1}$ diterima yang berarti bahwa keseluruhan variabel bebas aspek kebijakan pemerintah $\left(\mathrm{X}_{1}\right)$; aspek sosial budaya, dan ekonomi $\left(\mathrm{X}_{2}\right)$; aspek peranan lembaga terkait $\left(\mathrm{X}_{3}\right)$, aspek sumberdaya manusia $\left(\mathrm{X}_{4}\right)$; aspek keuangan $\left(\mathrm{X}_{5}\right)$, aspek teknis produksi dan operasional $\left(\mathrm{X}_{6}\right)$; dan aspek pasar dan pemasaran $\left(\mathrm{X}_{7}\right)$ secara simultan berpengaruh signifikan terhadap variabel terikat Y (kinerja UMKM). Hal ini berarti penentuan model regresi dengan memasukkan ketujuh variabel bebas tersebut sebagai faktor yang mempengaruhi kinerja UMKM di Kota Surabaya, merupakan hal yang tepat. Ketepatan penentuan model juga didukung oleh besarnya Koefisien Determinasi Berganda $\left(R^{2}\right)$ yang mencapai 0,654 .

Hasil penelitian ini sejalan dengan pendapat dari beberapa peneliti sebelumnya (Mc Commick et.al,1997; Zang, 2001; Laceiva, 2004; dan Haris Maupa, 2004 yang menyatakan bahwa kinerja sektor usaha mikro dan kecil dipengaruhi oleh dua faktor utama yakni faktor-faktor eksternal dan faktor-faktor internal. Faktor internal meliputi aspek SDM (pemilik, manajer, dan karyawan); aspek keuangan, aspek teknis produksi; dan aspek pemasaran. Sedangkan faktor eksternal terdiri dari kebijakan pemerintah, aspek sosial budaya dan ekonomi, serta peranan lembaga terkait seperti Pemerintah, Perguruan Tinggi, Swasta, dan LSM.

Dari hasil Uji Pengaruh Parsial (Uji t) seperti terlihat di Lampiran 1, terlihat bahwa nilai t hitung untuk X1 (aspek kebijakan pemerintah) sebesar 2,192 dengan nilai probabilitas atau signifikansi sebesar 0,031 (kurang dari $\alpha=0,05$ ). $\mathrm{Hal}$ ini berarti $\mathrm{H}_{0}$ ditolak atau $\mathrm{H}_{1}$ diterima yang berarti bahwa variabel bebas $\mathrm{X} 1$ (aspek kebijakan pemerintah) memiliki pengaruh positif dan signifikan terhadap variabel terikat Y (kinerja UMKM). Hasil penelitian ini membuktikan bahwa 
adanya kebijakan pemerintah yang tepat dapat memberikan pengaruh terhadap peningkatan kinerja UMKM. Kebijakan tersebut antara lain dapat berupa kebijakan pemerintah agar UMKM memiliki akses terhadap permodalan dan pembiayaan, pembinaan yang dilakukan oleh pemerintah terhadap UMKM melalui Dinas/SKPD terkait, peraturan dan regulasi pemerintah yang pro bisnis tehadap UMKM, dan penyiapan lokasi usaha dan penyediaan informasi dari pemerintah bagi UMKM.

Nilai t hitung untuk X2 (aspek sosial budaya, dan ekonomi) sebesar 0,081 dengan nilai probabilitas atau signifikansi sebesar 0,937 (lebih dari $\alpha=0,05$ ). Hal ini berarti $\mathrm{H}_{0}$ diterima atau $\mathrm{H}_{1}$ ditolak yang berarti bahwa variabel bebas $\mathrm{X} 2$ (aspek sosial budaya, dan ekonomi) memiliki pengaruh positif dan tidak signifikan terhadap variabel terikat Y (kinerja UMKM). Hasil penelitian ini membuktikan bahwa kinerja UMKM tidak terlalu terpengaruh oleh kondisi sosial budaya dan ekonomi.

Nilai t hitung untuk X3 (aspek peranan lembaga terkait) sebesar 2,313 dengan nilai probabilitas atau signifikansi sebesar 0,029 (kurang dari $\alpha=0,05$ ). $\mathrm{Hal}$ ini berarti $\mathrm{H}_{0}$ ditolak atau $\mathrm{H}_{1}$ diterima yang berarti bahwa variabel bebas $\mathrm{X} 3$ (aspek peranan lembaga terkait) memiliki pengaruh positif dan signifikan terhadap variabel terikat Y (kinerja UMKM). Hasil penelitian ini membuktikan bahwa lembaga terkait memiliki peranan yang signifikan dalam peningkatan kinerja UMKM. Peranan tembaga terkait tersebut antara lain dapat berupa bantuan permodalan yang diberikan oleh lembaga terkait kepada UMKM, bimbingan teknis/pelatihan yang diberikan oleh lembaga terkait kepada UMKM, pendampingan yang dilakukan oleh lembaga terkait kepada UMKM, dan monitoring dan evaluasi yang dilakukan oleh lembaga terkait kepada UMKM.

Nilai t hitung untuk X4 (aspek sumberdaya manusia) sebesar 3,405 dengan nilai probabilitas atau signifikansi sebesar 0,004 (kurang dari $\alpha=0,05$ ). Hal ini berarti $\mathrm{H}_{0}$ ditolak atau $\mathrm{H}_{1}$ diterima yang berarti bahwa variabel bebas $\mathrm{X} 4$ (aspek sumberdaya manusia) memiliki pengaruh positif dan signifikan terhadap variabel terikat Y (kinerja UMKM). Hal ini menunjukkan bahwa aspek sumberdaya manusia, yang terdiri dari tingkat pendidikan formal yang dicapai oleh pelaku UMKM, jiwa kepemimpinan yang dimiliki oleh pelaku UMKM, pengalaman/lama 
berusaha yang dicapai oleh pelaku UMKM, dan motivasi dan keterampilan yang dimiliki oleh pelaku UMKM, memiliki pengaruh positif dan signifikan terhadap kinerja UMKM.

Nilai t hitung untuk X5 (aspek keuangan) sebesar 3,132 dengan nilai probabilitas atau signifikansi sebesar 0,015 (kurang dari $\alpha=0,05$ ). Hal ini berarti $\mathrm{H}_{0}$ ditolak atau $\mathrm{H}_{1}$ diterima yang berarti bahwa variabel bebas $\mathrm{X} 5$ (aspek keuangan) memiliki pengaruh positif dan signifikan terhadap variabel terikat $Y$ (kinerja UMKM). Hal ini menunjukkan bahwa aspek keuangan, yang terdiri dari rasio modal sendiri terhadap total dana yang digunakan sebagai modal usaha (dalam persen) dan tingkat keuntungan UMKM (sebagai prosentase dari modal yang dipakai), memiliki pengaruh positif dan signifikan terhadap kinerja UMKM.

Nilai t hitung untuk X6 (aspek teknis produksi dan operasional) sebesar 2,507 dengan nilai probabilitas atau signifikansi sebesar 0,023 (kurang dari $\alpha=0,05)$. Hal ini berarti $\mathrm{H}_{0}$ ditolak atau $\mathrm{H}_{1}$ diterima yang berarti bahwa variabel bebas X6 (aspek teknis produksi dan operasional) memiliki pengaruh positif dan signifikan terhadap variabel terikat Y (kinerja UMKM). Hal ini menunjukkan bahwa aspek teknis produksi dan operasional, yang terdiri dari tersedianya bahan baku yang memadai bagi kebutuhan UMKM, tersedianya mesin dan peralatan yang memadai bagi UMKM, dan penggunaan teknologi modern oleh UMKM, dapat meningkatkan kinerja UMKM.

Nilai t hitung untuk X7 (aspek pasar dan pemasaran) sebesar 3,214 dengan nilai probabilitas atau signifikansi sebesar 0,012 (kurang dari $\alpha=0,05$ ). Hal ini berarti $\mathrm{H}_{0}$ ditolak atau $\mathrm{H}_{1}$ diterima yang berarti bahwa variabel bebas $\mathrm{X} 7$ (aspek pasar dan pemasaran) memiliki pengaruh positif dan signifikan terhadap variabel terikat Y (kinerja UMKM). Hal ini menunjukkan bahwa aspek pasar dan pemasaran, yang terdiri dari permintaan pasar terhadap produk UMKM yang relatif besar, kegiatan promosi yang dilakukan oleh UMKM, dan tersedianya saluran distribusi bagi UMKM, dapat meningkatkan kinerja UMKM.

\section{Kesimpulan}

Berdasarkan hasil penelitian yang telah dilakukan dapat diambil kesimpulan sebagai berikut: 
1. Aspek kebijakan pemerintah; aspek sosial budaya, dan ekonomi; aspek peranan lembaga terkait; aspek sumberdaya manusia; aspek keuangan; aspek teknis produksi dan operasional; dan aspek pasar dan pemasaran secara simultan berpengaruh signifikan terhadap kinerja UMKM. Hal tersebut terbukti dari hasil uji $\mathrm{F}$ yang menunjukkan nilai $\mathrm{F}$ hitung sebesar 4,314 dengan nilai probabilitas atau signifikansi sebesar 0,000. Nilai signifikansi ini lebih kecil dari level of significance $(\alpha)$ dalam penelitian sebesar 0,05 . Hal ini berarti penentuan model regresi dengan memasukkan ketujuh variabel bebas tersebut sebagai faktor yang mempengaruhi kinerja UMKM di Kota Surabaya, merupakan hal yang tepat. Ketepatan penentuan model juga didukung oleh besarnya Koefisien Determinasi Berganda $\left(\mathrm{R}^{2}\right)$ yang mencapai 0,654.

2. Uji t membuktikan bahwa dari tujuh varibel bebas yang dimasukkan dalam model regresi linier berganda, enam variabel bebas memiliki pengaruh signifikan terhadap kinerja UMKM yaitu aspek kebijakan pemerintah; aspek peranan lembaga terkait; aspek sumberdaya manusia; aspek keuangan; aspek teknis produksi dan operasional; dan aspek pasar dan pemasaran. Sedangkan satu variabel bebas tidak memiliki pengaruh yang signifikan terhadap kinerja UMKM yaitu aspek sosial budaya, dan ekonomi.

3. Aspek kebijakan pemerintah memiliki pengaruh positif dan signifikan terhadap kinerja UMKM. Hal ini membuktikan bahwa adanya kebijakan pemerintah agar UMKM memiliki akses terhadap permodalan dan pembiayaan, pembinaan yang dilakukan oleh pemerintah terhadap UMKM melalui Dinas/SKPD terkait, peraturan dan regulasi pemerintah yang pro bisnis tehadap UMKM, dan penyiapan lokasi usaha dan penyediaan informasi dari pemerintah bagi UMKM dapat meningkatkan kinerja UMKM.

4. Aspek sosial budaya, dan ekonomi memiliki pengaruh positif tetapi tidak signifikan terhadap kinerja UMKM. Hal ini menunjukkan bahwa kinerja UMKM tidak terlalu terpengaruh oleh kondisi sosial budaya dan ekonomi.

5. Aspek peranan lembaga terkait memiliki pengaruh positif dan signifikan terhadap kinerja UMKM. Hal ini membuktikan bahwa bantuan permodalan yang diberikan oleh lembaga terkait kepada UMKM, bimbingan 
teknis/pelatihan yang diberikan oleh lembaga terkait kepada UMKM, pendampingan yang dilakukan oleh lembaga terkait kepada UMKM, dan monitoring dan evaluasi yang dilakukan oleh lembaga terkait kepada UMKM memiliki pengaruh positif dan signifikan terhadap kinerja UMKM.

6. Aspek sumberdaya manusia memiliki pengaruh positif dan signifikan terhadap kinerja UMKM. Hal ini menunjukkan bahwa tingkat pendidikan formal yang dcapai oleh pelaku UMKM, jiwa kepemimpinan yang dimiliki oleh pelaku UMKM, pengalaman/lama berusaha yang dicapai oleh pelaku UMKM, dan motivasi dan keterampilan yang dimiliki oleh pelaku UMKM, memiliki pengaruh positif dan signifikan terhadap kinerja UMKM.

7. Aspek keuangan memiliki pengaruh positif dan signifikan terhadap kinerja UMKM. Hal ini menunjukkan bahwa semakin baiknya aspek keuangan, dilihat dari semakin meningkatnya rasio modal sendiri terhadap total dana yang digunakan sebagai modal usaha (dalam persen) dan semakin tingginya tingkat keuntungan UMKM (sebagai prosentase dari modal yang dipakai), dapat meningkatkan kinerja UMKM.

8. Aspek teknis produksi dan operasional memiliki pengaruh positif dan signifikan terhadap kinerja UMKM. Hal ini menunjukkan bahwa aspek teknis produksi dan operasional, yang terdiri dari tersedianya bahan baku yang memadai bagi kebutuhan UMKM, tersedianya mesin dan peralatan yang memadai bagi UMKM, dan penggunaan teknologi modern oleh UMKM, dapat meningkatkan kinerja UMKM.

9. Aspek pasar dan pemasaran memiliki pengaruh positif dan signifikan terhadap kinerja UMKM. Hal ini menunjukkan bahwa aspek pasar dan pemasaran, yang terdiri dari permintaan pasar terhadap produk UMKM yang relatif besar, kegiatan promosi yang dilakukan oleh UMKM, dan tersedianya saluran distribusi bagi UMKM, dapat meningkatkan kinerja UMKM.

\section{Saran}

1. Kelompok usaha mikro, kecil dan menengah. (UMKM) telah terbukti mampu menjadi motor penggerak perekonomian. Peran UMKM dalam perekonomian dapat dilihat dari penyerapan tenaga kerja oleh UMKM yang mencapai 97,22\% 
dari total angkatan kerja di Indonesia pada tahun 2010. Selain itu, UMKM juga memberikan kontribusi yang lebih besar terhadap PDB Indonesia dibandngkan kelompok usaha besar, yaitu mencapai angka 57,83\% pada tahun 2010. Oleh karena itu, program pemberdayaan UMKM seharusnya memperoleh perhatian yang serius baik oleh pemerintah pusat maupun Pemerintah Kota Surabaya.

2. Program pemberdayaan UMKM seharusnya diarahkan pada upaya untuk meningkatkan kinerja UMKM. Peningkatan kinerja UMKM tersebut perlu dilakukan terhadap perbaikan dua faktor utama yakni faktor-faktor eksternal dan faktor-faktor internal. Faktor internal meliputi aspek SDM (pemilik, manajer, dan karyawan); aspek keuangan, aspek teknis produksi; dan aspek pemasaran. Sedangkan faktor eksternal terdiri dari kebijakan pemerintah, aspek sosial budaya dan ekonomi, serta peranan lembaga terkait seperti Pemerintah, Perguruan Tinggi, Swasta, dan LSM..

3. Pelaku UMKM harus berupaya untuk meningkatkan kualitas sumber daya manusia (SDM), baik dari sisi pendidikan, pengalaman, jiwa kepemimpinan, maupun motivasi untuk maju. Peningkatan kualitas SDM tersebut dapat difasilitasi oleh pemerintah maupun lembaga yang terkait dengan pembinaan dan pengembangan UMKM.

4. Pelaku UMKM juga harus berupaya untuk memperbaiki aspek keuangan, aspek teknis produksi, dan aspek pemasaran. Perbaikan aspek keuangan, aspek teknis produksi, dan aspek pemasaran tersebut dapat difasilitasi oleh pemerintah maupun lembaga yang terkait dengan pembinaan dan pengembangan UMKM.

5. Pemerintah Kota Surabaya harus lebih bersungguh-sungguh dalam upaya meningkatkan kinerja UMKM, dengan membuat kebijakan agar UMKM memiliki akses terhadap permodalan dan pembiayaan, melakukan pembinaan terhadap UMKM melalui Dinas/SKPD terkait, mengeluarkan peraturan dan regulasi yang pro bisnis tehadap UMKM, dan melakukan penyiapan lokasi usaha dan penyediaan informasi bagi UMKM.

6. Lembaga terkait memiliki peranan yang sangat penting dalam upaya pemberdayaan UMKM. Lembaga terkait tersebut meliputi pemerintah, 
perguruan tinggi, perusahaan swasta, dan LSM. Oleh karena itu, perlu ada upaya untuk mendorong agar lembaga terkait memiliki peran yang makin besar dalam meningkatkan kinerja UMKM, melalui pemberian bantuan permodalan bagi UMKM, pemberian bimbingan teknis/pelatihan kepada UMKM, pemberian pendampingan kepada UMKM, dan monitoring \& evaluasi kepada UMKM

\section{DAFTAR PUSTAKA}

Acs, Z. and Audretsch, D., 1990, The Economics of Small Firms: A European Challenge, Kluwer Academic Publishers, Norwall, MA.

Ariawati, 2005, "Strategi Bertahan Usaha Kecil dalam Menghadapi Krisis Ekonomi (Studi Industri Kecil Konveksi di Salatiga)”, Jurnal Ekonomi dan Bisnis Vol VII No.2

Brock, W. and Evans, D., 1986, The Economics of Small Business: Their Roles and Regulations in US Economy, Holmes \& Meier Publishers, Teaneck, NJ.

Crijns,H. And Ooghi, 2000, Growth Paths of Medium Sized Entrepreneurial Companies. De Vlerick School Voor Management, University of Ghent.

Demirbag, M., Tatoglu, E., Tekinkus, M. and Zaim, S., 2006, “An analysis of the relationship between TQM implementation and organizational performance: evidence from Turkish SMEs", Journal of Manufacturing Technology Management, Vol. 17 No. 6, pp. 829-47.

Ghozali, Imam, 2001, Aplikasi Analisis Multivariate dengan Program SPSS, Cetakan Pertama, Badan Penerbit Universitas Diponegoro, Semarang

Laceiva, 2004, Knowledge-Based Resources, Entrepreneurial Orientation, and The Performance Of small and Medium-Seze Businesses, Strategic Management Journal, 24: 1307-1314

Maupa, Haris. 2004. Faktor-Faktor yang Menentukan Pertumbuhan Usaha Kecil di Sulawesi Selatan. Disertasi Program Pascasarjana Unhas. Tidak dipublikasikan.

McCormick, D., M.N. Kinyanjui and G. Ongile., 1997, Growth and Barriers to Growth Among Nairobi,s Small and Medium Size Garment Producers. 
World Dev., Vol.25, No.7, pp. 1095-1110.

Mulyanto, 2008, Hubungan Antara Lingkungan Eksternal, Opientasi Strategik Dan Kinerja Perusahaan (Studi Empiris pada Industri Manufaktur MenengahKecil di Kota Semarang), Fakultas Ekonomi, UNDIP.

Muttaqien, 2008, Hubungan Antara Lingkungan Eksternal, Opientasi Strategik Dan Kinerja Perusahaan (Studi Empiris pada Industri Manufaktur MenengahKecil di Kota Semarang), Fakultas Ekonomi, UNDIP

Radhi, Suhardi, 2008, "Dinamika Usaha Kecil dan Menengah (UKM), Analisis Konsentrasi Regional UKM di Indonesia 1999-2001”, Jurnal Ekonomi Pembangunan, Volume 9 No.2, Yogyakarta, UII

Undang-Undang No. 20 tahun 2008 tentang Usaha Mikro, Kecil, dan Menengah, Jakarta.

Wilkinson, 2002, Small, Micro, and Medium Enterprise Development: Expanding the Option for Debt and Equity Finance. Financial Sector Workshop, National Economic Development and Labour Council (NEDLAC), Johanesburg, South Africa, Iris, April 6.

Wisardja, I Wayan. 2000. Analisis Lingkungan Industri Kerajinan Ukiran Kayu di Kabupaten Gianyar Propinsi Bali, Program Pascasarjana Universitas Brawijaya, Malang.

Zhang, Y. 2001. Learning Function and Small Business Growth, Management Accounting Journal, MCB University Press, Vol 15 No. 26, pp. 228-231 